\title{
Micronutrient and sodium foliar contents of yellow passion plants as a function of biofertilizers
}

\author{
Lourival Ferreira CAVALCANTE ${ }^{1}$, Ítalo Herbert Lucena CAVALCANTE ${ }^{2 *}$, Geílson Dias Dos SANTOS ${ }^{2}$
}

${ }^{1}$ Soil Science and Agricultural Engineering, Centre of Agrarian Sciences, Federal University of Paraíba, Areia, Brazil

lofeca@cca.ufpb.br

${ }^{2}$ Agronomy, Campus Profa Cinobelina Elvas, Federal University of Piauí, Bom Jesus, Brazil

italohlc@ufpi.br

${ }^{*}$ Correspondence and reprints

Fruits, 2008 , vol. 63 , p. 27-36 (C) 2008 Cirad/EDP Sciences All rights reserved DOI: $10.1051 /$ fruits:2007042 www.fruits-journal.org

RESUMEN ESPAÑOL, p. 36

\section{Micronutrient and sodium foliar contents of yellow passion plants as a} function of biofertilizers.

Abstract - Introduction. Mineral status related to micronutrients and sodium is important to obtain high yields, despite the fact that no standardized contents have been established for yellow passion fruit. Biofertilizers have emerged as an important component of the integrated nutrient supply system aiming at an environmentally better nutrient supply because they have a direct action on micronutrient uptake. In this context, the objective of our research was to evaluate the micronutrient and sodium foliar contents of yellow passion fruit plants fertilized with two different biofertilizers in Brazil. Materials and methods. A randomized block design with treatments distributed in a factorial arrangement $(2 \times 5)$ referring to two biofertilizers (simple and enriched with $\mathrm{Zn}, \mathrm{Mg}, \mathrm{Mn}, \mathrm{Cu}, \mathrm{Co}, \mathrm{Fe}, \mathrm{Ca}, \mathrm{B}$ and $\mathrm{Mo}$ ) and five doses of each biofertilizer $\left[\left(0.0,0.6,1.2,1.8\right.\right.$ and 2.4) L.plant $\left.{ }^{-1}\right]$ was adopted. Results of boron, copper, iron, manganese, zinc and sodium foliar contents were submitted to variance analysis, the Tukey test and regression analysis. Results and discussion. The results indicate that enriched biofertilizer promoted the statistically highest foliar contents of all elements. The biofertilizer doses applied had different effects on foliar contents of the elements studied. Conclusion. Micronutrient and sodium foliar contents of yellow passion fruit were affected by both the type and doses of biofertilizers. Simple biofertilizer promoted optimum supplies of boron and iron, while enriched biofertilizer supplied boron, iron, manganese and zinc.

Brazil / Passiflora edulis / fertilizer application / biofertilizers / mineral content / leaves / tissue analysis

Teneurs foliaires en oligoéléments et en sodium de plants de passiflore jaune en fonction de biofertilisants.

Résumé - Introduction. Le statut minéral en oligoéléments et en sodium est important pour l'obtention de hauts rendements, bien qu'aucunes teneurs de référence n'aient encore été établies pour le plant de passiflore jaune. Les biofertilisants sont devenus une composante importante d'un système intégré de nutrition des plants visant à une meilleure fertilisation vis-à-vis de l'environnement car ces produits agissent directement sur l'absorption des oligoéléments. Dans ce contexte, nos recherches ont cherché à évaluer les teneurs foliaires en oligoéléments et en sodium pour des plants de passiflore jaune fertilisés avec deux biofertilisants différents au Brésil. Matériel et méthodes. Un dispositif en blocs randomisés, avec des traitements répartis selon un arrangement factoriel $(2 \times 5)$ se rapportant à deux biofertilisants (simple et enrichi avec du $\mathrm{Zn}, \mathrm{Mg}, \mathrm{Mn}, \mathrm{Cu}, \mathrm{Co}, \mathrm{Fe}, \mathrm{Ca}, \mathrm{B}$ et $\mathrm{Mo})$ et à cinq doses de chaque biofertilisant $[(0,0,0,6$, $1,2,1,8$ et 2,4$) \mathrm{L}_{\text {plant }}{ }^{-1}$ ] a été adopté. Les résultats de teneur foliaire en bore, cuivre, fer, manganèse, zinc et sodium ont été soumis à une analyse de variance, un test de Tukey et une analyse de régression. Résultats et discussion. Les résultats ont montré que le biofertilisant enrichi a favorisé les teneurs foliaires statistiquement les plus élevées pour tous les éléments. Les doses de biofertilisant appliquées ont eu différents effets sur les teneurs foliaires des éléments étudiés. Conclusion. Les teneurs foliaires en oligoéléments et en sodium des plants de passiflore jaune ont été affectées par le type et les doses de biofertilisants. Le biofertilisant simple a favorisé les apports maximaux en bore et fer, alors que le biofertilisant enrichi a favorisé les apports en bore, fer, manganèse et zinc.

Brésil / Passiflora edulis / fertilisation / biofertilisant / teneur en éléments minéraux / feuille / analyse de tissus 


\section{Introduction}

Yellow passion fruit (Passiflora edulis f. flavicarpa Deg.) is one of the most potentially fruitful plants in Brazil, where the climatic and soil conditions are favorable for its cultivation. Brazil is the main world producer of yellow passion fruit [1], which has good flavor, high nutritional value, pharmacological applications and is especially consumed as juice.

Nutritional equilibrium, including micronutrients, during the yellow passion fruit cycle is important to obtain high yields. Adversely, no standardized foliar levels of nutrients have been established yet, despite the stated adequate ranges: boron, (25100) $\mathrm{mg} \cdot \mathrm{kg}^{-1}$; copper, (5-20) $\mathrm{mg} \cdot \mathrm{kg}^{-1}$ iron, (100-200) $\mathrm{mg} \cdot \mathrm{kg}^{-1}$; manganese, (50200) $\mathrm{mg} \cdot \mathrm{kg}^{-1}$; and zinc, (45-80) $\mathrm{mg} \cdot \mathrm{kg}^{-1}$ [2]. Mineral fertilizers have been used on yellow passion fruit cultivation, which are expensive for small and medium producers (the majority in Brazil) and promote, as time goes on, environmental problems such as soil salinization [3].

Nevertheless, some researchers have indicated the use of alternative fertilizers such as municipal garbage [4] and biofertilizer [5]; the latter is a recently coined term whose exact definition is still unclear, but which most commonly refers to the use of soil microorganisms to increase the availability and uptake of mineral nutrients for plants [6]. Microorganisms of Aerobacter, Flavobacterium and Thiobacillus genera [7] detach, but the effects of mycorrhizas and humic substances are very important. Yellow passion fruit is highly dependent on mycorrhizas when grown in soil with a low phosphorus level [8], while the complexing properties of humic substances increase micronutrient availability for plants [9]. Furthermore, biofertilizers can provide humic substances to soil [5] and enhance mycorrhizal activity in soil [10].

In recent years, biofertilizers have emerged as an important component of the integrated nutrient supply system and have a great potential to improve crop yields through environmentally better nutrient supplies [10]. Nevertheless, most research has been realized during the initial devel- opment of plants, which led to the present study, specifically about the yellow passion fruit plant, which is a social and economically important fruitful plant in Brazil.

Vessey [6] argued that biofertilizer has a direct action on micronutrient uptake, i.e., the physiological activity of biofertilizer results in increased supply of nutrients to the plant. However, it is important to observe that plants regulate their tissue mineral composition against electrochemical gradients through active and passive processes [11], depending on soil chemical and physical characteristics. Furthermore, plant species differ characteristically in their capacity to take up micronutrients when grown in the same soil, which, generally, reflects typical species differences in the requirement of these nutrients for growth, development, flowering and fruiting, and the leaf micronutrient contents.

In this area, the objective of our research was to evaluate the micronutrient and sodium foliar contents of yellow passion fruit plants fertilized with two biofertilizers in Brazil.

\section{Materials and methods}

\subsection{Plant materials and growth conditions}

Yellow passion fruit (Passiflora edulis) plants propagated by seeds were used in this study.

The study was conducted for one year (2002-2003) on the 'Macaquinhos' experimental farm of the Federal University of Paraiba, near Remigio (northeastern Brazil). The site is located at $470 \mathrm{~m}$ above sea level, with average precipitation of $920 \mathrm{~mm} \cdot \mathrm{year}^{-1}$, temperature between $(24 \text { and } 26)^{\circ} \mathrm{C}$ and average air humidity of $75 \%$.

The soil is a Xerorthent [12], with a sandy texture (793, 107 and 100$) \mathrm{g} \cdot \mathrm{kg}^{-1}$ of sand, silt and clay, respectively, $1.66 \mathrm{~kg} \cdot \mathrm{dm}^{-3}$ bulk density, $0.38 \mathrm{~m}^{3} \cdot \mathrm{m}^{-3}$ total porosity, $8 \mathrm{~g} \cdot \mathrm{dm}^{-3}$ organic matter, $6 \mathrm{mg} \cdot \mathrm{dm}^{-3}$ phosphorus, $78 \mathrm{mg} \cdot \mathrm{dm}^{-3}$ potassium, $1.1 \mathrm{cmol}_{\mathrm{C}} \cdot \mathrm{dm}^{-3}$ calcium, $\quad 0.8 \mathrm{cmol}_{\mathrm{C}} \cdot \mathrm{dm}^{-3}$ magnesium, 


\begin{tabular}{|c|c|c|c|c|c|c|c|c|c|c|c|}
\hline \multirow[t]{2}{*}{ Biofertilizer } & $N$ & $P$ & K & $\mathrm{Ca}$ & $\mathrm{Mg}$ & B & $\mathrm{Cu}$ & $\mathrm{Fe}$ & $\mathrm{Mn}$ & $\mathrm{Zn}$ & $\mathrm{Na}$ \\
\hline & \multicolumn{5}{|c|}{$\left(g \cdot L^{-1}\right)$} & \multicolumn{6}{|c|}{$\left(\mathrm{mg} \cdot \mathrm{L}^{-1}\right)$} \\
\hline Simple & 0.76 & 0.05 & 0.82 & 0.21 & 0.13 & 4.00 & 6.00 & 77.00 & 10.00 & 16.00 & 81 \\
\hline Enriched & 0.19 & 0.22 & 2.70 & 0.24 & 0.15 & 438 & 332 & 155 & 961 & 1700 & 328 \\
\hline
\end{tabular}

$0.2 \mathrm{cmol}_{\mathrm{C}} \cdot \mathrm{dm}^{-3}$ aluminium, $2.6 \mathrm{cmol}_{\mathrm{C}} \cdot \mathrm{dm}^{-3}$ hydrogen and $5.3 \mathrm{pH}$. This is a good soil for yellow passion fruit cultivation [13].

Plants, spaced $2 \mathrm{~m}$ between rows and $3 \mathrm{~m}$ between plants, were drip-irrigated daily with two self-regulating emitters per plant for a flow of $3.75 \mathrm{~L} \cdot \mathrm{h}^{-1}$ each. Each hole, 30 days before planting, received $10 \mathrm{~L}$ of bovine manure (C:N, 16:1).

\subsection{Treatments and experimental design}

For leaf content analyses, four replicates of 180 leaves (in each repetition, 12 leaves per plant and 15 plants were sampled) were taken from normal shoots, from the middle part of the canopy, following the cardinal points at $120 \mathrm{~d}$ after transplanting. According to the recommendations of Malavolta et al. [14], the third and fourth leaves from the apex of the shoot were collected to do the nutritional analyses.

The experimental design was randomized blocks with treatments distributed in a factorial arrangement $(2 \times 5)$ referring to two biofertilizers [simple and enriched] (table I) and five doses of each biofertilizer, which were of $[0.0,0.6,1.2,1.8$ and 2.4) $\mathrm{L}$-plant ${ }^{-1}$, corresponding to $(0,25,50$, 75 and 100)\% of biofertilizer in $15 \mathrm{~L}$ of the solution applied per $\mathrm{m}^{2}$ as proposed by Santos [15]. Therefore, the experiment concerned 10 treatments with four repetitions of 15 plants per parcel, that is to say, 600 plants.

Biofertilizer doses were distributed bimonthly in a soil area of $0.283 \mathrm{~m}^{2}(30 \mathrm{~cm}$ radius around the plant stem) under a [water:biofertilizer] ratio of [1:1].

\subsection{Preparation of biofertilizers}

Both biofertilizers were obtained by anaerobic fermentation.

Simple biofertilizer consisted of [water + fresh bovine manure] at a ratio of [1:1] (in volume), under anaerobic fermentation for $30 \mathrm{~d}$, as proposed by Santos [15].

Enriched biofertilizer, suggested by Meirelles et al. [16], consisted of water + fresh bovine manure + a protein mix + nutrient sources. After combining water and fresh bovine manure at a ratio of [1:1] (in volume), the protein mix and a nutrient source were added every $2 \mathrm{~d}$.

The protein mix consisted of $1 \mathrm{~L}$ milk + 1 L sugarcane honey $+100 \mathrm{~mL}$ bovine blood $+100 \mathrm{~g}$ bone flour $+200 \mathrm{~g}$ calcareous $(20 \%$ $\mathrm{CaO}$ and $14 \% \mathrm{MgO})+200 \mathrm{~g}$ of natural phosphate $\left(24 \% \mathrm{P}_{2} \mathrm{O}_{5}\right.$ and $\left.\left.26 \% \mathrm{CaO}\right)\right]$.

For the nutrient source, the nutrients were added in the following sequence: (a) zinc sulfate, $2 \mathrm{~kg}$ ( $9 \% \mathrm{Zn}, 13 \% \mathrm{~S}$ ); (b) magnesium sulfate, $2 \mathrm{~kg}(9 \% \mathrm{Mg}, 13 \% \mathrm{~S})$; (c) manganese sulfate, $300 \mathrm{~g}$ (26\% Mn, 14-15\% S); (d) copper sulfate, $300 \mathrm{~g}(13 \% \mathrm{Cu}, 11 \% \mathrm{~S})$; (e) cobalt sulfate, $50 \mathrm{~g}(20 \% \mathrm{Co}, 11 \% \mathrm{~S})$; (f) iron sulfate, $300 \mathrm{~g}(19 \% \mathrm{Fe}, 10-11 \% \mathrm{~S})$; (g) calcium chloride, $2 \mathrm{~kg}(27.2 \% \mathrm{Ca}$, $48.3 \% \mathrm{Cl})$; (h) boric acid, $1 \mathrm{~kg}(17 \% \mathrm{~B})$; (i) sodium molybdate, $100 \mathrm{~g}(39 \% \mathrm{Mo})$, thus totaling nine additions to the protein mix.

\subsection{Chemical analysis}

Leaves were chemically analyzed after washing and rinsing with distilled water and drying at $70{ }^{\circ} \mathrm{C}$ for $48 \mathrm{~h}$. The $\mathrm{B}, \mathrm{Cu}, \mathrm{Fe}, \mathrm{Mn}$, $\mathrm{Zn}$ and $\mathrm{Na}$ contents in the plant material were determined by atomic-absorption spectrophotometry [17]. 


\section{L.F. Cavalcante et al.}

\section{Table II.}

Leaf micronutrient and sodium contents $\left(\mathrm{mg} \cdot \mathrm{kg}^{-1}\right)$ for yellow passion fruit plants as a function of types (simple and enriched) of biofertilizers tested in Brazil (Remigio, PB).

$\begin{array}{lcccccc}\text { Treatment } & \mathrm{B} & \mathrm{Cu} & \mathrm{Fe} & \mathrm{Mn} & \mathrm{Zn} & \mathrm{Na} \\ \text { Simple } & 23.08 \mathrm{~b} & 67.20 \mathrm{~b} & 120.6 \mathrm{~b} & 20.20 \mathrm{~b} & 22.20 \mathrm{~b} & 1889.80 \mathrm{~b} \\ \text { Enriched } & 122.60 \mathrm{a} & 84.20 \mathrm{a} & 145.6 \mathrm{a} & 34.80 \mathrm{a} & 29.33 \mathrm{a} & 2244.00 \mathrm{a} \\ \text { Significant minimum difference } & 9.72 & 7.60 & 3.17 & 2.49 & 2.39 & 164.57 \\ \text { Coefficient of variation (\%) } & 17.53 & 13.19 & 10.78 & 11.89 & 12.17 & 10.45\end{array}$

Data followed by different letters in columns are significantly different according to the Tukey test $(P \leq 0.01)$.

F values of the analysis of variance.

\begin{tabular}{|c|c|c|c|c|c|c|}
\hline Source of variation & B & $\mathrm{Cu}$ & $\mathrm{Fe}$ & $\mathrm{Mn}$ & $\mathrm{Zn}$ & $\mathrm{Na}$ \\
\hline Biofertilizer (B) & $455.53^{\star *}$ & $21.74^{\star \star}$ & $22.76^{\star \star}$ & $149.41^{\star \star}$ & $38.81^{\star *}$ & $20.16^{\star \star}$ \\
\hline Biofertilizer doses (D) & $69.56^{\star \star}$ & $100.91^{\star *}$ & $29.79^{\star \star}$ & $34.41^{* *}$ & $52.08^{\star *}$ & $46.55^{\star \star}$ \\
\hline Interaction $(\mathrm{B} \times \mathrm{D})$ & $62.53^{\star \star}$ & $4.08^{\star \star}$ & $1.08 \mathrm{~ns}$ & $11.82^{\star \star}$ & $8.56^{\star \star}$ & $3.73^{\star *}$ \\
\hline
\end{tabular}

\subsection{Statistical analysis}

Statistical analyses included analysis of variance (ANOVA), mean separation of biofertilizers using the Tukey test, and simple regression to separation of biofertilizer doses [15], according to the recommendations of Ferreira [18]. All the calculations were performed using the SAS Statistical Program [19] and terms were considered significant at $P \leq 0.01$.

\section{Results and discussion}

Biofertilizers significantly influenced foliar contents of all elements studied, with the highest values registered for enriched biofertilizer as previously expected. Indeed, independently of the element studied, leaf micronutrient and sodium contents were invariably and statistically higher with enriched biofertilizer than with simple biofertilizer (table II)

Significant interactions between biofertilizers and the doses applied were registered, except for iron foliar contents.

\subsection{Micronutrients}

In a general form, boron leaf results presented the greatest range between simple biofertilizer and enriched biofertilizer (a difference of nearly $99 \mathrm{mg} \cdot \mathrm{kg}^{-1}$ between the two treatments, table II). This could be caused by the significantly higher boron content of enriched biofertilizer compared with the simple biofertilizer content (table I), and by the known competition relation between $\mathrm{N}$ and B. Possibly the higher nitrogen content of simple biofertilizer $(75 \%$ more than enriched biofertilizer, table I) had a negative effect on boron uptake by roots of yellow passion fruit. This competition for binding sites was previously registered by Malavolta et al. [14] and Marschner [20], inferring that boron values in plants can be depressed by increasing nitrate concentrations in soil. Nevertheless, this is not a general situation because both nitrogen and boron are absorbed as different compounds $\left(\mathrm{NH}_{4}^{+}\right.$ and $\mathrm{NO}_{3}^{-} ; \mathrm{H}_{3} \mathrm{BO}_{3}$ and $\mathrm{H}_{2} \mathrm{BO}_{3}^{-}$, respectively) and the competition degree perhaps depends on these compounds' proportion in soil. It is important to note that both $\mathrm{N}$ 

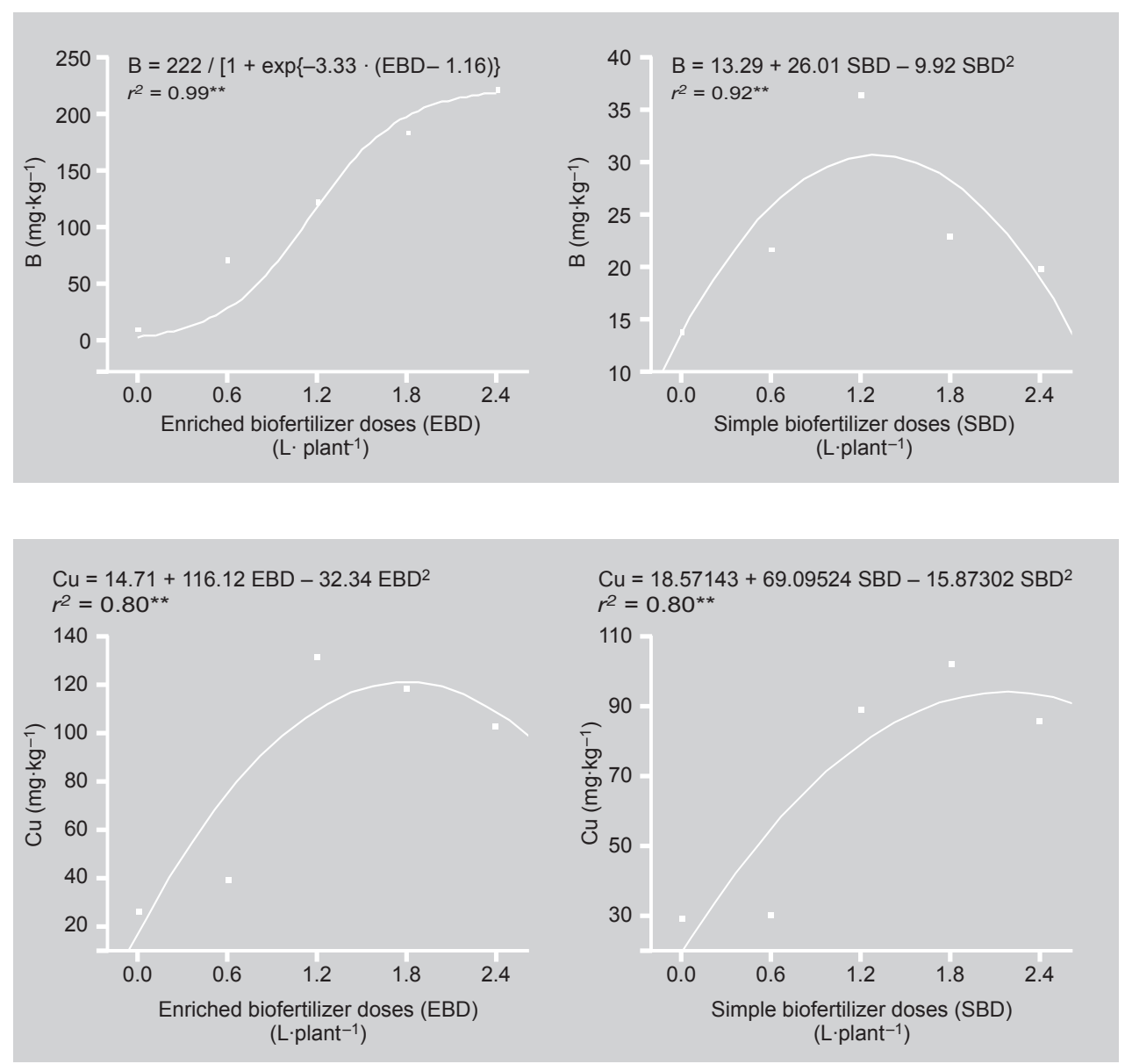

and B uptake is by mass flow. A significant difference was also registered in relation to biofertilizer doses; while enriched biofertilizer presented a sigmoid data distribution (figure 1), simple biofertilizer identified a quadratic adjustment of the data with a minimum fit of $0.92 \mathrm{~L}$-plant ${ }^{-1}$, with a peak at 1.2 L-plant ${ }^{-1}$ (figure 1). Boron foliar content promoted by simple biofertilizer is compatible with the $26.39 \mathrm{mg} \cdot \mathrm{kg}^{-1}$ average reported by Konsaeng et al. [21] and $29.1 \mathrm{mg} \cdot \mathrm{kg}^{-1}$ of Borges et al. [22].

In relation to copper, enriched biofertilizer presented an average just 20\% higher than simple biofertilizer. This superiority was expected to be greater, due to the substantially higher copper content of enriched biofertilizer observed in table $I$, although simple biofertilizer may have promoted microorganism action, reproduction or increment in soil. Also, in a study about both biofertilizers (simple and enriched), Tratch and Bettiol [23] verified different filamentous fungi and bacteria as Bacillus sp. on simple biofertilizer; for enriched biofertilizer, these authors registered a drastic reduction of microorganisms after salt addition containing micronutrients. According to Cavalcante et al. [13], salts increase osmotic pressure and directly affect microorganisms. Both biofertilizers presented quadratic regression adjustment, although a difference in the peak was registered, i.e., at $1.2 \mathrm{~L} \cdot$ plant $^{-1}$ for enriched biofertilizer and $1.8 \mathrm{~L} \cdot$ plant $^{-1}$ for simple biofertilizer (figure 2). The copper results of the present study are significantly above the $28.5 \mathrm{mg} \cdot \mathrm{kg}^{-1}$ of Carvalho et al. [24] but no visual toxic symptoms were observed.

It is important to observe that simple biofertilizer possibly enhanced mycorrhizal activity in soil, as observed by Wu et al. [10],
Figure 1.

Boron foliar contents of yellow passion plants as a function of different enriched and simple biofertilizer doses given to 120-d-old plants in Brazil (Remigio, PB).

Figure 2.

Copper foliar contents of yellow passion plants as a function of different enriched and simple biofertilizer doses given to 120-d-old plants in Brazil (Remigio, PB). 
Figure 3.

Iron foliar contents of yellow passion plants as a function of different enriched and simple biofertilizer doses given to 120-d-old plants in Brazil (Remigio, PB).

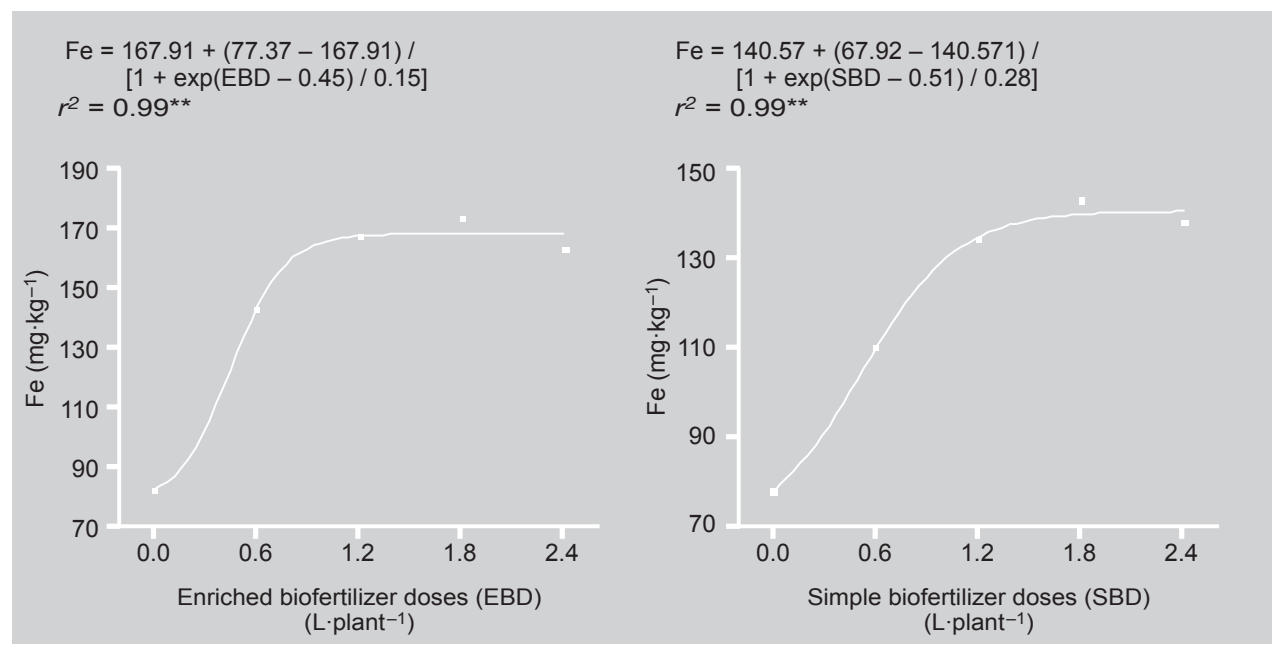

and the association with arbuscular mycorrhizal fungi in soils with low and medium phosphorus values (as observed in the present study) favors growth of passion fruit and possibly mineral nutrition, despite the lack of specificity between the host and the symbiotic species [8]. In relation to microorganisms in a general form, Bollag and Stozky [7] inferred that soil microorganisms could enhance nutrient uptake by nearly $200 \%$.

Iron foliar contents obtained with enriched biofertilizer were significantly above those obtained with simple biofertilizer, as also observed for boron and copper, but a lower difference between iron contents in the respective biofertilizers and the foliar content of yellow passion fruit was registered. Wang et al. [25] argued that some rhizospheric bacteria produce siderophores (they bind $\mathrm{Fe}^{3+}$ and help to maintain it in solution) and there is evidence that some plant species absorb $\mathrm{Fe}^{3+}$ siderophores that are important because of iron being preferentially absorbed by plants as $\mathrm{Fe}^{2+}$ [20], although there are controversies in the scientific literature regarding the importance of this complex in iron plant nutrition. Regression analysis of biofertilizer doses and iron contents identified sigmoid data distribution for both biofertilizers (figure 3) showing that, at $1.8 \mathrm{~L} \cdot$ plant $^{-1}$, the maximum iron foliar content was found, after which it tended to stabilize. This is in contrast to Mohammad and Athamneh's [26] study about another alternative fertilizer (sewage sludge); they concluded that the lowest iron content was obtained by the control treatment. The iron foliar results with both biofertilizers studied are very much higher than those registered by Carvalho et al. [24].

Biological transformations of many micronutrients are determinant for their availability, mainly in soils with excess humidity. Thus, both iron and manganese soil concentrations are influenced by Aerobacter, Flavobacterium and Thiobacillus genera, which act on the oxireduction process, therefore controlling the bioavailability of these nutrients [7].

In spite of manganese, the use of simple biofertilizer made it possible to observe an average $\mathrm{Mn}$ foliar content significantly (approximately 41\%) lower than that obtained with enriched biofertilizer (table II). This superiority was expected to be greater because enriched biofertilizer presented almost 100 times more manganese than simple biofertilizer. Perhaps the known antagonism of calcium and magnesium to manganese explains this result, because enriched biofertilizer presented $12.5 \%$ and $13.3 \%$ more calcium and magnesium, respectively. There was a quadratic regression for the manganese foliar contents and biofertilizer doses studied for both simple biofertilizer and enriched biofertilizer (figure 4). Manganese foliar results increased $(37.5 \%$ with simple biofertilizer and $65.9 \%$ with enriched biofertilizer) from (0 to 1.2 ) L-plant ${ }^{-1}$ doses applied, losing this tendency and decreasing until $2.4 \mathrm{~L} \cdot$ plant $^{-1}$. 

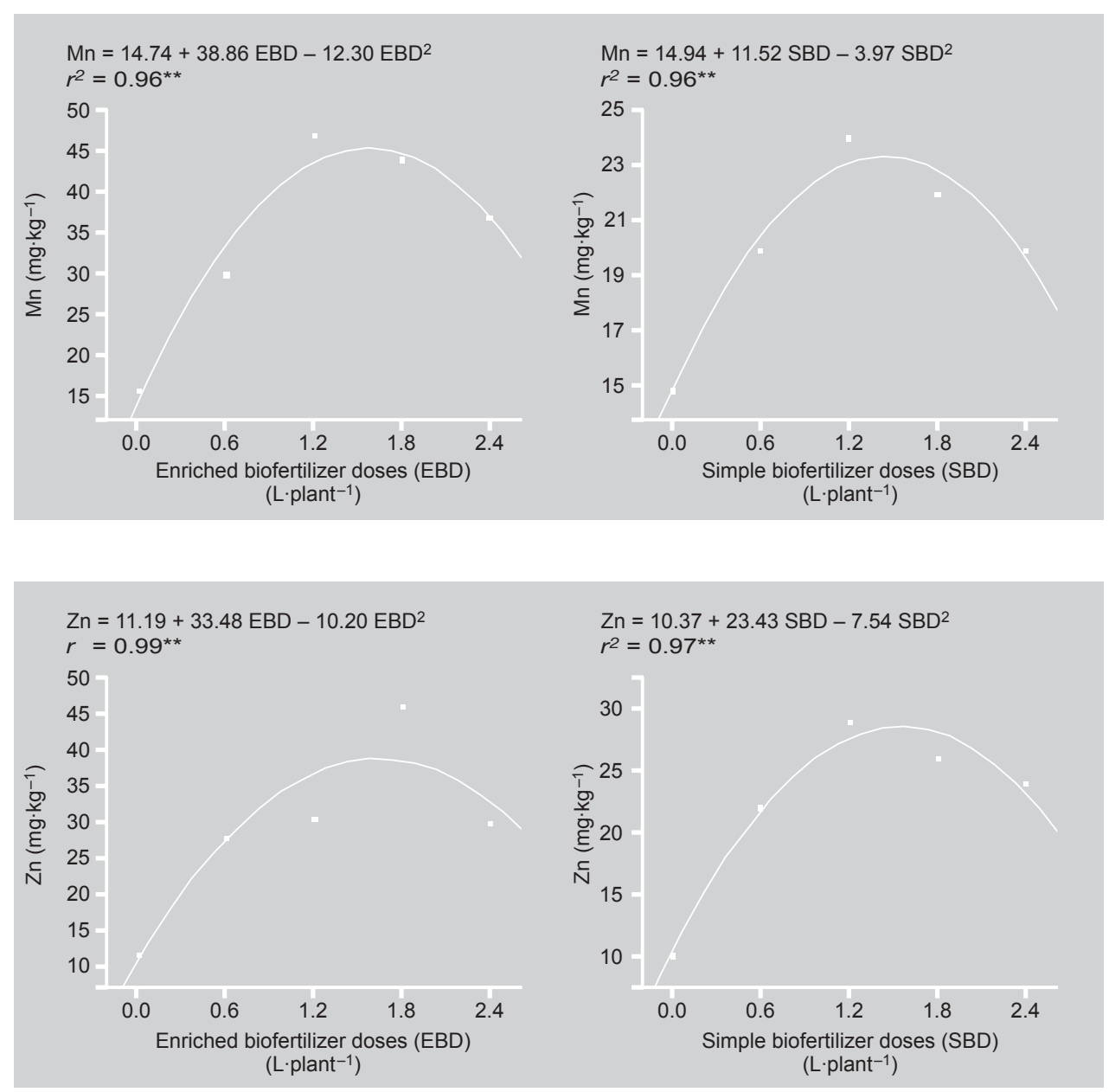

The average contents are lower than the $75.6 \mathrm{~g} \cdot \mathrm{kg}^{-1}$ indicated by Carvalho et al. [24].

Zinc foliar contents ranged from (22.2 to 29.3) $\mathrm{mg} \cdot \mathrm{kg}^{-1}$, respectively, for simple biofertilizer and enriched biofertilizer (table II), showing that enriched biofertilizer promoted notably higher manganese compared with simple biofertilizer. Zinc availability is affected by microorganisms' action on $\mathrm{pH}$, organic acid production, organic acid mineralization and ZnS oxidation by Thiobacillus [7]; therefore, perhaps simple biofertilizer enhanced microorganism activity in soil and promoted higher availability of zinc. According to Hedge et al. [27], simple biofertilizers contain different types of microorganisms, which have an ability to convert nutritionally important elements from unavailable into available forms through bio- logical processes. Accordingly, Kleinschmidt and Gedermann [28] proved that stunted non-mycorrhizal seedlings were $\mathrm{Cu}-$ and $\mathrm{Zn}$-deficient, while mycorrhizal inoculation enabled seedlings to absorb adequate amounts of these nutrients. Regression analysis of biofertilizer doses and zinc content shows quadratic adjustment of data with $0.97 \mathrm{~L}$ plant $^{-1}$ (simple biofertilizer) and $0.99 \mathrm{~L}^{- \text {plant }^{-1}}$ (enriched biofertilizer) minimum fit, although simple biofertilizer promoted the maximum zinc content firstly in relation to enriched biofertilizer (figure 5). Zinc averages (table II) are close to those of Carvalho et al. [24].

Thus, in a general way, it is relevant to note that by increasing the biofertilizer doses applied, the micronutrient foliar content was invariably enhanced until it
Figure 4.

Manganese foliar contents of yellow passion plants as a function of different enriched and simple biofertilizer doses given to 120-d-old plants in Brazil (Remigio, PB).

Figure 5.

Zinc foliar contents of yellow passion plants as a function of different enriched and simple biofertilizer doses given to 120-d-old plants in Brazil (Remigio, PB). 


\section{L.F. Cavalcante et al.}

Figure 6.

Sodium foliar contents of yellow passion plants as a function of different enriched and simple biofertilizer doses given to 120-d-old plants in Brazil (Remigio, PB).

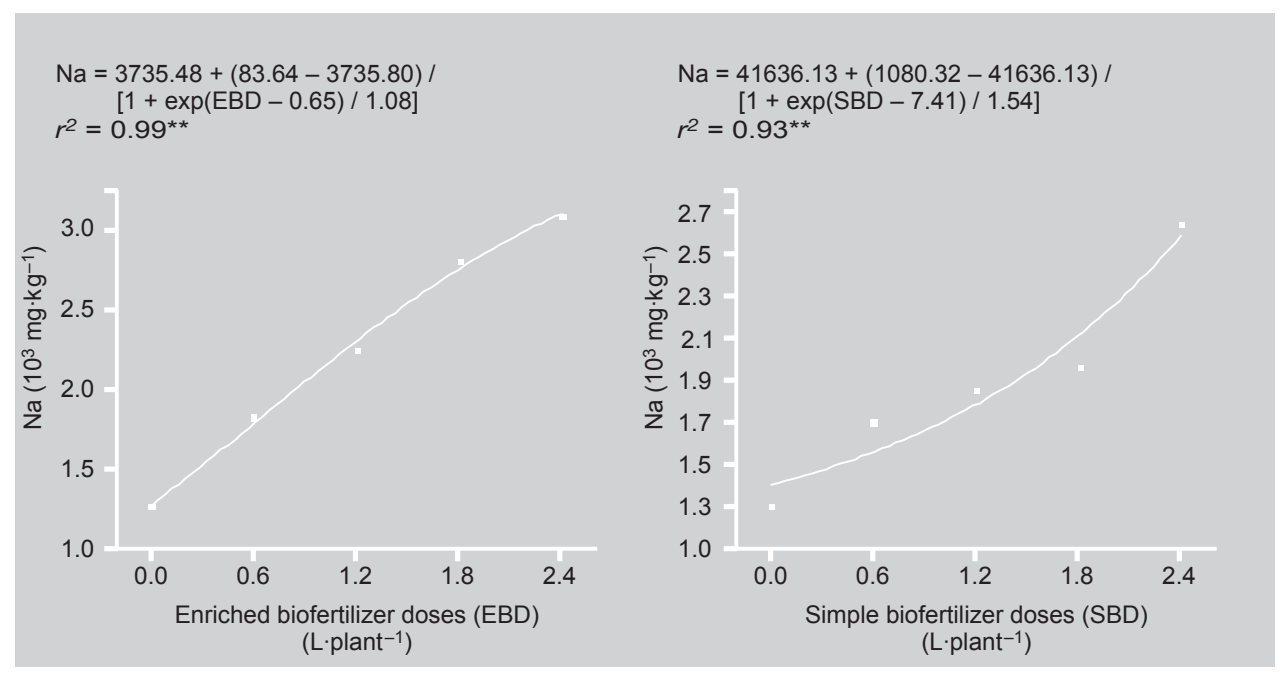

reached a peak, independently of the micronutrient studied. Beyond the content of the nutrients in biofertilizers, microorganisms and mycorrhizal activity and interactions between ions, humic substances have an important role that is still not clear, but Lagreid et al. [5] evidenced that biofertilizer can provide humic substances in soil. According to Nardi et al. [29], the effects of humic substances appear to be selective and variable and the mechanisms are not easily explainable, owing to the complex and still unknown nature of these substances.

When compared with the World fertilizer use manual [2] ranges of supply, yellow passion fruit plants fertilized with simple biofertilizer presented optimum supply at 1.2 L.plant ${ }^{-1}$ for boron and from (0.6 to 2.4) $\mathrm{L}$. plant ${ }^{-1}$ for iron, while copper results were above and manganese and zinc below the optimum supply range.

In relation to plants fertilized with enriched biofertilizer, the optimum supplies were registered at $0.6 \mathrm{~L} \cdot$ plant $^{-1}$ for boron, from (0.6 to 2.4) $\mathrm{L}^{\text {plant }}{ }^{-1}$ for iron, $1.2 \mathrm{~L}$ plant $^{-1}$ for manganese and $1.8 \mathrm{~L}$. plant ${ }^{-1}$ for zinc. As also obtained for copper, all doses applied promoted averages higher than the supply range previously reported [2].

\subsection{Sodium}

As also observed for micronutrients, sodium foliar content was significantly higher with enriched biofertilizer than with simple biofertilizer, but the lowest difference between the two biofertilizers was verified, nearly $15 \%$. Sigmoid data distribution was registered in the two cases, showing an increment in sodium foliar content from ( 0 to 2.4) $\mathrm{L}_{\text {plant }}{ }^{-1}$ and a tendency to stabilize (figure O). Plants that received $2.4 \mathrm{~L}$ presented high sodium contents but an absence of toxic effects, showing that passion fruit presents higher tolerance to salts than that suggested by Ayers and Westcot [30], i.e., a fruitful plant was ranked as salt-sensitive. Ayers and Westcot's [30] classification also diverges from those of Soares et al. [31], Cavalcante et al. [32] and Cavalcante et al. [13] that ranked passion fruit as reasonably salt-sensitive.

\section{Conclusions}

Therefore, our studies demonstrate that: (i) micronutrient and sodium foliar contents of yellow passion fruit are affected by both the type and dose of biofertilizer; (ii) simple biofertilizer promotes optimum supplies of boron and iron, while enriched biofertilizer promotes supplies of boron, iron, manganese and zinc; (iii) simple and enriched biofertilizers induced high copper foliar contents; (iv) sodium foliar content is enhanced by biofertilizer doses, reaching high levels, but no visual toxic symptoms were observed. 


\section{References}

[1] Anon., Agrianual: Anuário Estatístico da Agricultura Brasileira, Argos Comunicação, São Paulo, Brazil, 2005.

[2] Anon., World fertilizer use manual, BASF Agric. Res. Stn., Paris, France, 1992.

[3] Cavalcante L.F., Cavalcante Í.H.L., Uso da água salina na agricultura, in: Cavalcante L.F., Lima E.M. (Eds.), Algumas frutíferas tropicais e a salinidade, FUNEP, Jaboticabal, Brazil, 2006.

[4] Al-Redhaiman K.N., Nassar I.N., Al-Salamah I.S., Effect of the municipal garbage on the growth of lettuce, Asian J. Plant Sci. 2 (2003) 731-737.

[5] Lagreid M., Bockman O.C., Kaarstad O., Agriculture, fertilizers and the environment, CABI, Cambridge, UK, 1999.

[6] Vessey J.LK., Plant growth promoting rhizobacteria as biofertilizers, Plant Soil 255 (2003) 571-586.

[7] Bollag J.M., Stozky G., Soil biochemistry, Marcel Dekker, New York, USA, 2000.

[8] Cavalcante U.M.T., Maia L.C., Costa C.M.C., Santos V.F., Mycorrhizal dependency of passion fruit (Passiflora edulis f. flavicarpa), Fruits 56 (2001) 317-324.

[9] Stevenson F.J., Organic matter-micronutrient reactions in soil, in: Mortverdt J.J., Cox F.R., Shuman L.M., Welch R.M. (Eds.), Micronutrients in agriculture, Soil Sci. Soc. Am., Madison, USA, 1991.

[10] Wu S.C., Cao Z.H., Li Z.G., Cheung K.C., Wong M.H., Effects of biofertilizer containing $\mathrm{N}$-fixer, $\mathrm{P}$ and $\mathrm{K}$ solubilizers and $\mathrm{AM}$ fungi on maize growth: a greenhouse trial, Geoderma 125 (2005) 155-166.

[11] Bot L. le, Adamowicz S., Robin P., Modelling plant nutrition of horticultural crops: a review, Sci. Hortic. 74 (1998) 47-82.

[12] Anon., Soil taxonomy: a basic system of soil classification for marketing and interpreting soil surveys, Soil survey staff, USDA, Handbook N 436, Washington, USA, 1999.

[13] Cavalcante L.F., Costa J.R.M., Olliveira F.K.D., Cavalcante Í.H.L., Araújo F.A.R., Produção do maracujazeiro-amarelo irrigado com água salina em covas protegidas contra perdas hídricas, Irrig. 10 (2005) 229240.
[14] Santos A.C.V., Efeitos nutricionais e fitossanitários do biofertilizante líquido a nível de campo, Rev. Bras. Frutic. 13 (1991) 275279.

[15] Meirelles L., Bracagioli Neto A., Meirelles A.L., Biofertilizantes enriquecidos: caminho sadio da nutrição e propagação de plantas, CAE, Ipê, Brazil, 1997.

[16] Malavolta E., Vitti G.C., Oliveira S.A., Avaliação do estado nutricional das plantas: princípios e aplicações, 2nd edition, Potafos, Piracicaba, Brazil, 1997.

[17] Chapman H.D., Pratt P.F., Method of analysis for soils, plants and waters, Agric. Publ. Off., Berkekey, USA, 1961.

[18] Ferreira P.V.F., Estatística experimental aplicada à agronomia, EDUFAL, Maceió, Brazil, 2000.

[19] Anon., SAS/STAT User's Guide, version 4.0.2., SAS Inst. Inc., Cary, USA, 2000.

[20] Marschner $\mathrm{H}_{\text {., }}$ Mineral nutrition of higher plants, 6th edition, Acad. Press, London, UK, 2005.

[21] Konsaeng S., Dell B., Rerkasem S., A survey of woody tropical species for boron retranslocation, Plant Prod. Sci. 8 (2005) 338-341.

[22] Borges A.L., Caldas R.C., Lima A.A., Almeida I., Efeito de doses de NPK sobre os teores de nutrientes nas folhas e no solo, e na produtividade do maracujazeiro amarelo, Rev. Bras. Frutic. 24 (2002) 208-213.

[23] Tratch R., Bettiol W., Efeito do biofertilizante sobre o crescimento micelial e a germinação de esporos de alguns fungos fitopatogênicos, Pesqui. Agropecu. Bras. 32 (1997) 1131-1139.

[24] Carvalho A.J.C., Martins D.P., Monnerat P.H., Bernardo S., Silva J.A., Teores de nutrientes foliares no maracujaueiro-amarelo associados à estação fenológica, adubação potássica e mâminas de irrigação, Rev. Bras. Frutic. 23 (2001) 403-408.

[25] Wang Y., Brown H.N., Crowley D.E., Szaniszlo P.J., Evidence for direct utilization of a siderophore, ferrioxamine $B$, in axenically grown cucumber, Plant Cell Environ. 16 (1993) 579-585.

[26] Mohammad M.J., Athamneh B.M., Changes in soil fertility and plant uptake of nutrients and heavy metals in response to sewage 
sludge application to calcareous soils, J. Agron. 3 (2004) 229-236.

[27] Hedge D.M., Dwived B.S., Sudhakara S.N., Biofertilizers for cereal production in India - a review, Indian J. Agric. Sci. 69 (1999) 73-83.

[28] Kleinschmidt G.D., Gedermann J.W., Stunting of citrus seedlings in fumigated nursery soils related to the absence of endomycorrhizae, Phytopathol. 62 (1972) 1447-1453.

[29] Nardi S., Pizzeghello D., Muscolo A., Vianello A., Physiological effects of humic substances on higher plants, Soil Biol. Biochem. 34 (2002) 1527-1536.
[30] Ayers R.S., Westcot D.W., A qualidade da água na agricultura, UFPB, Campina Grande, Brazil, 1999.

[31] Soares F.A., Gheyi H.R., Viana S.B.A., Uyedac C.A., Fernandes P.D., Water salinity and initial development of yellow passion fruit, Sci. Agric. 59 (2002) 491-497.

[32] Cavalcante L.F., Santos J.B., Santos C.J.O., Feitosa Filho J.C., Lima E.M., Cavalcante Í.H.L., Germinação de sementes e crescimento inicial de maracujazeiros irrigados com água salina em diferentes volumes de substrato, Rev. Bras. Frutic. 24 (2002) 748751.

\section{Contenidos foliares en oligoelementos y en sodio de plántulas de pasiflora amarilla en función de biofertilizantes.}

Resumen - Introducción. El estado mineral en oligoelementos y en sodio es importante para la obtención de altos rendimientos, a pesar de que aún no se haya establecido ningún contenido de referencia para la plántula de pasiflora amarilla. Los biofertilizantes se han vuelto un componente importante de un sistema integrado de nutrición de plántulas enfocadas a una fertilización mejor en relación con el medioambiente, ya que estos productos actúan directamente sobre la absorción de los oligoelementos. En este contexto, nuestros estudios pretendieron evaluar los contenidos foliares en oligoelementos y en sodio para plántulas de pasiflora amarilla fertilizadas con dos biofertilizantes diferentes en Brasil. Material y métodos. Se adoptó un dispositivo en bloques randomizados, con tratamientos repartidos según una distribución factorial $(2 \times 5)$ en relación con dos biofertilizantes (simple y enriquecido con $\mathrm{Zn}, \mathrm{Mg}, \mathrm{Mn}, \mathrm{Cu}, \mathrm{Co}, \mathrm{Fe}, \mathrm{Ca}, \mathrm{B}$ y $\mathrm{Mo})$ y con cinco dosis de cada biofertilizante $[(0,0$, 0,6, 1,2, 1,8 et 2,4) L-plant ${ }^{-1}$ ]. Los resultados de contenido foliar en boro, cobre, hierro, magnesio, cinc y sodio se sometieron a un análisis de variancia, a un test de Tukey y a un análisis de regresión. Resultados y discusión. Los resultados mostraron que el biofertilizante enriquecido favoreció los contenidos foliares más elevados estadísticamente para todos los elementos. Las dosis de biofertilizante aplicadas tuvieron efectos diferentes en los contenidos foliares de los elementos estudiados. Conclusión. Los contenidos foliares en oligoelementos y en sodio de las plántulas de pasiflora amarilla fueron afectados por el tipo y las dosis de biofertilizantes. El biofertilizante simple favoreció los aportes máximos de boro y hierro, mientras que el biofertilizante enriquecido favoreció los aportes en boro, hierro, magnesio y cinc.

Brasil / Passiflora edulis / aplicación de abonos / biofertilizantes / contenido mineral / hojas / análisis de tejidos 